\title{
Arenavirus Infections
}

\section{Infecciones por arenavirus}

\author{
Salim Mattar V1* Ph.D, Camilo Guzmán T ${ }^{1}$ M.Sc, Alfonso Calderón R ${ }^{1}$ M.Sc, \\ Marco González Tous ${ }^{1}$ M.Sc.
}

${ }^{1}$ Universidad de Córdoba, Facultad de Medicina Veterinaria y Zootecnia, Instituto de Investigaciones Biológicas del trópico, Montería, Córdoba, Colombia. Correspondence: mattarsalim@hotmail.com

Received: August 2016; Accepted: March 2017.

\begin{abstract}
The infectious syndromes associated with arenaviruses in South America are four: febrile syndrome of viral origin; Haemorrhagic fevers with or without neurological involvement; Aseptic meningitis and meningo-encephalitis. Among the Arenavirus of the new world is the Tacaribe complex where the viruses are found: Junín (Argentina), Guanarito (Venezuela), Machupo (Bolivia) and Sabiá (Brazil), which are characterized by hemorrhagic fevers. In Colombia the arenavirus Pichindé was isolated in 1965, from the rodent Oryzomys albigularis, in the valley of Pichindé (Valle del Cauca). This arenavirus produces a persistent infection in its host and is not pathogenic for the man. There is evidence of the circulation of the Guanarito virus in rodents from Córdoba, but there are no cases diagnosed in humans; In Colombia, the genome of the lymphocytic choriomeningitis virus was detected in the brains of rodents Mus musculus. The diagnosis is based on the knowledge of local epidemiology and the suspicion of a patient with fever in endemic areas, where infections such as malaria, dengue and leptospirosis, sepsis of bacterial origin and rickectomy have been excluded. Virus isolation in the feverish period is the gold standart, but it implies contact with the virus that is highly infectious, which represents a public health problem. Serology has been used for diagnosis, but there is no commercial evidence and only research groups and large public health laboratories have these tests. Most of the patients present a moderate severity, which needs adequate hydration, antipyretics and anti-inflammatories. All patients with severe signs should be aggressively treated. The use of drugs has not demonstrated a decrease in mortality but a significant reduction in viremia.
\end{abstract}

Keywords: Arenavirus, reservoirs, rodentia, public health (Source: DeCS).

\section{RESUMEN}

Los síndromes infecciosos asociados a arenavirus en América del sur son cuatro: síndrome febril de origen viral; fiebres hemorrágicas con o sin compromiso neurológico; meningitis asépticas y meningoencefalitis. Entre los Arenavirus del nuevo mundo, está el complejo Tacaribe donde se encuentran los virus: Junín (Argentina), Guanarito (Venezuela), Machupo (Bolivia) y Sabiá (Brasil), que se caracterizan por causar fiebres hemorrágicas. En Colombia fue aislado el arenavirus Pichindé en 1965, del roedor Oryzomys albigularis, en el valle de Pichindé (Valle del Cauca). Este arenavirus produce una infección persistente en su hospedero y no es patógeno para el hombre. Hay evidencias de la circulación del virus Guanarito en roedores de Córdoba, pero no existen casos diagnosticados en humanos; en Sincelejo (Colombia) se detectó el genoma del virus coriomeningitis linfocítica en cerebros de roedores Mus musculus. El diagnóstico se basa en el conocimiento de la epidemiología local y la sospecha de un 
paciente con un cuadro febril en zonas endémicas, donde se han excluido infecciones como: malaria, dengue y leptospirosis, sepsis de origen bacteriano y rickectsiosis. El aislamiento viral en periodo febril es el gold standart, pero implica el contacto con el virus que es altamente infectante, lo que representa un problema de salud pública. Se ha usado la serología para el diagnóstico, pero no hay pruebas comerciales y sólo grupos de investigación y grandes laboratorios de salud pública poseen estas pruebas. La mayor parte de los pacientes presentan un cuadro de gravedad moderada, que necesita una adecuada hidratación, antipiréticos y antiinflamatorios. Todos los pacientes con signos de severos deben tener un manejo agresivo. El uso de medicamentos no ha demostrado una disminución de la mortalidad, pero si una reducción significativa de la viremia.

Palabras claves: Arenavirus, reservorios, roedores, salud pública (Fuente: DeCS).

\section{INTRODUCTION}

Among the Arenaviruses of the new world, the Tacaribe serocomplex shows the following: Junín (Argentina), Guanarito (Venezuela), Machupo (Bolivia) and Sabiá (Brazil), characterized by causing hemorrhagic fever (1-4). In Colombia the Pichindé Arenavirus (5) was isolated in 1965, from the liver, spleen, and kindneys of Oryzomys albigularis rodents, in a forest located in the Pichindé valley, of the department of Valle del Cauca. This arenavirus produces a persistent infection in its natural host, and it is not pathogenic for humans. Knowledge of the clinical manifestations of arenavirus infections in South America is based on the data collected from patients infected with Junín, Manchupo, and Guanarito viruses (6-8). Only human infections secondary to this virus have epidemiological value in a region (9). In our country, there is certainty that the Guanarito virus circulates in rodents in the department of Córdoba, but so far there have been no cases of diagnosed human infection (10). A 3.1\% seroprevalence of IgC arenavirus antibodies was reported in the Emberá-Katio community in the alto Sinú region (Colombia) (11). Another study conducted in Sincelejo (Colombia) found a $10 \%$ seroprevalence, and the lymphocytic choriomeningitis genome was detected in 16 brain samples of Mus musculus rodents (12).

Etiological agent. The Arenaviridae family is comprised by a single genus, arenavirus, which includes twenty-two members formally acknowledged by the International Commitee for Taxonomy of Viruses (ICTV). It includes the Lassa serocomplex, an old-world group that includes autochthonous viruses from Africa, the worldwide distributed lymphocytic choriomeningitis virus (LCM), and the newworld Tacaribe serocomplex, which includes the native American viruses (Figure 1), subdivided in lineages $A, B$, and $C$. All of the arenaviruses causing hemorrhagic fever in humans belong to lineage $B$. In addition to

\section{INTRODUCCIÓN}

Entre los Arenavirus del nuevo mundo, en el denominado complejo Tacaribe se encuentran los virus: Junín (Argentina), Guanarito (Venezuela), Machupo (Bolivia) y Sabiá (Brasil), que se caracterizan por causar fiebres hemorrágicas (1-4). En Colombia fue aislado Arenavirus Pichindé (5) en 1965, a partir de hígado, bazo y riñón del roedor Oryzomys albigularis, en un bosque en el valle de Pichindé, departamento del Valle del Cauca. Este arenavirus produce una infección persistente en su hospedero natural y no es patógeno para el hombre. El conocimiento de las manifestaciones clínicas de las infecciones por arenavirus en Suramérica proviene de los datos recopilados en pacientes con infección por los virus Junín, Manchupo y Guanarito (6-8). Sólo las infecciones en humanos secundarias a estos virus tienen valor epidemiológico en una región (9). En nuestro país, existe certeza de que el virus Guanarito circula en roedores en el departamento de Córdoba, pero hasta el momento no existen casos diagnosticados en humanos (10). En una comunidad indígena Emberá-Katio, del alto Sinú (Colombia), se reportó una seropositividad del 3.1\% para anticuerpos IgG de arenavirus (11). Otro estudio realizado en Sincelejo (Colombia) encontró una seroprevalencia del $10 \%$ y se detectó el genoma del virus de la coriomeningitis linfocítica en 16 muestras de cerebro, de roedores Mus musculus (12).

Agente etiológico. La familia Arenaviridae está formada por un único género, arenavirus que incluye veintidós miembros formalmente reconocidos por el International Commitee for Taxonomy of Viruses (ICTV). Comprende el serocompeljo Lassa, grupo del viejo mundo que incluye virus autóctonos de África, el virus de la Coriomeningitis Linfocitaria (LCM), de distribución mundial y el serocomplejo Tacaribe grupo del nuevo mundo en el cual están incluidos virus nativos del continente americano (Figura 1), subdivididos en los linajes A, B y C. Todos los arenavirus que causan fiebre hemorrágica en los humanos son del linaje B. Adicionalmente a los virus antes citados, existen otros virus incluidos en el linaje B 


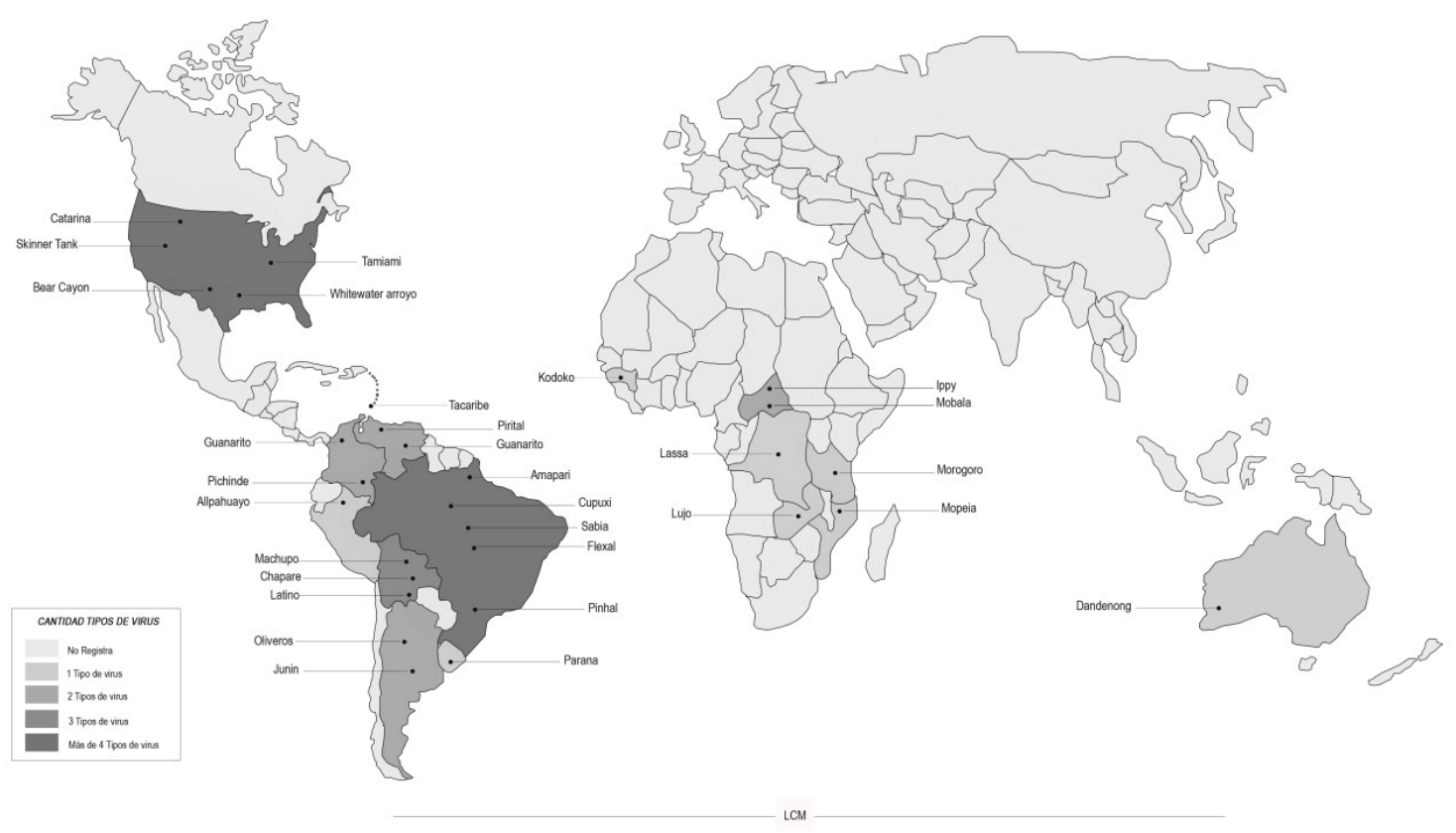

Figure1. Distribution of arenaviruses in the world.

the above-mentioned viruses, there are other $B$-lineage viruses that do not infect humans, including Amapari, Cupuxi, and Tacaribe (Table 1 ). Members of the Arenaviridae family are negative chain single-stranded RNA viruses, viral particles are spherical with diameters ranging from 50 to $300 \mathrm{~nm}$. The have a helicoidally symmetrical capsid and include a variable number of ribosomes appearing grainy or sandy in electronic microphotography images $(9,13,14,15)$.

Pathogenesis. The virus-cell interaction begins when the $\mathrm{G} 1$ protein of the viral spikes and the cell receptor make contact. In the case of the old-world arenavirus and the C-lineage of the new world, Alpha-dystroglican is the receptor with which the $\mathrm{G} 1$ protein interacts. For new-world lineages $A$ and $B$, transferrin is the receptor $(1,14,16,17)$. The virus-receptor interaction causes the cell membrane to curve, to enable endocytosis, followed by the fusion of the virus membrane and the endocytic vesicle mediated by the G2 conformation change. Later, the RNA nucleic capsid proteins that act as molds for viral transcription and replication in the cytosol $(16,17)$.

Clinical signs. There are four infectious syndromes associated to arenaviruses in South America, to wit: viral febrile syndrome; hemorrhagic fever with or without neurologic compromise; aseptic meningitis, que no causan infección los humanos, dentro de estos tenemos Amapari, Cupuxi y Tacaribe (Tabla 1). Los miembros de la familia Arenaviridae son virus ARN monocatenarios de cadena negativa, las partículas virales son esféricas con un diámetro que va desde 50 hasta 300nm. Poseen una cápside con simetría helicoidal e incluyen un número variable de ribosomas en su interior con aspecto granuloso o arenoso en imágenes de microfotografías electrónicas $(9,13,14,15)$.

Patogénesis. La interacción virus-célula se inicia con el contacto de la proteína G1 de las espículas virales y el receptor celular. El alfa distroglicano es el receptor celular con el cual interactúa la proteína $\mathrm{G} 1$, en el caso de los arenavirus del viejo mundo y el linaje $C$ del nuevo mundo. Para los linajes $A$ y $B$ del nuevo mundo el receptor es transferrina $(1,14,16,17)$. La interacción virusreceptor provoca la curvatura de la membrana celular, para dar lugar a la endocitosis, seguida de la fusión entre las membranas del virus y la vesícula endocítica mediada por el cambio conformacional G2 Posteriormente, se liberan las nucleocápside ARN proteína que actúan como moldes para la transcripción y replicación viral en el citosol $(16,17)$.

Manifestaciones clínicas. Síndromes infecciosos asociados a Arenavirus en América del Sur son cuatro: síndrome febril de origen viral; fiebres hemorrágicas con o sin compromiso neurológico; meningitis asépticas; meningoencefalitis. En las infecciones diseminadas en 
Table 1. Description of arenaviruses in the Americas.

\begin{tabular}{|c|c|c|c|c|}
\hline Virus (Reservoir) & Lineage & Distribution & Detection & Disease \\
\hline Junín (Calomys musculinus) & NW B & Argentina & 1958 & Argentinian hemorrhagic fever \\
\hline Machupo (Calomys callosus; Calomys laucha) Chapare & NW B & Bolivia & $1963-2008$ & Bolivian hemorrhagic fever \\
\hline Guanarito (Zygodontomys brevicauda) & NW B & Venezuela & 1990 & Venezuelan hemorrhagic fever \\
\hline Sabia & NW B & Brazil & 1990 & Hemorrhagic fever \\
\hline LCMV (Mus musculus) & OW & Mundial & 1934 & Lymphocytic choriomeningitis \\
\hline Flexal (Oryzomys sp) & NW A & Brazil & 1975 & ND \\
\hline Pichindé (Oryzomys albigularis) & NW A & Colombia & 1967 & ND \\
\hline Paraná (Oryzomys buccinatus) & NW A & Paraguay & 1965 & ND \\
\hline Allpahuayo (Oecomys bicolor) & NW A & Peru & 2001 & ND \\
\hline Pirital (Sigmodon alstoni) & NW A & Venezuela & 1997 & ND \\
\hline Tacaribe (Artibeus sp) + & NW B & Trinidad & 1956 & ND \\
\hline Cupuxi (Oryzomys capito) & NW B & Brazil I & 1998 & ND \\
\hline Amapari (Oryzomys capito; Neacomys guianae) & NW B & Brazil & 1964 & ND \\
\hline Oliveros (Bolomys obscures) & NW C & Argentina & 1989 & ND \\
\hline Latino (Calomys callosus) & NW C & Bolivia & 1965 & ND \\
\hline Whitewater arroyo (Neotoma sp) & NW rec & USA & 1996 & ND \\
\hline Tamiami (Sigmodon hispidus) & NW rec & USA & 1965 & ND \\
\hline Bear Canyon (Peromyscus sp) & NW rec & USA & 2002 & ND \\
\hline Pinhal* (Calomys tener) & NW C & Brazil & $?$ & ND \\
\hline Catarina* (Neotoma micropus) & NW & USA & 2007 & ND \\
\hline Skinner Tank* (Neotoma mexicana) & NW & USA & 2008 & ND \\
\hline
\end{tabular}

LCMV: Lymphocytic choriomeningitis; ND: undetermined; OW: old world; NW: new world.

NW A: new world lineage A. NW B: new world lineage B. NW C: new world lineage C NW rec: recombinant.

$+=$ only arenavirus isolated from bats. *virus not yet recognized by ICTV.

meningoencephalitis. For infections spread in transplanted patients $(6,18)$ such as hantavirus, there are some symptoms and clinical signs that characterize an infection with this virus family, but their presence or lack thereof is neither sensible or specific enough to differentiate clinical picture caused by other infectious agents. Thus, diagnosis largely depends on local epidemiology and clinician's suspicions when facing a compatible picture and lab tests have resulted negative for the most common infectious agents $(6,19,20,21)$.

Viral febrile syndrome. The initial clinical picture of an arenavirus infection differs from the one caused by other viruses such as dengue. In studies carried out in Venezuela, most patients infected with Guanarito virus and admitted into a hospital located in endemic areas were diagnosed with dengue when admitted (15). The clinical picture shows an insidious onset with fever, shivers, headache, photophobia and generalized muscle pain. Other symptoms include nausea, vomiting, moderate diarrhea, orthostatic hypotension, pacientes transplantados $(6,18)$, como en el caso de los hantavirus, existen algunos síntomas y signos clínicos que son característicos de la infección de esta familia de virus, pero su presencia o ausencia no es lo suficientemente sensible o específica, para permitir diferenciación de cuadros clínicos causados por otros agentes infecciosos. Por esto su diagnóstico depende en gran medida de la epidemiología local y de la sospecha del clínico, ante un paciente con un cuadro clínico compatible y las pruebas de laboratorio han resultado negativas para otros agentes infecciosos más comunes $(6,19,20,21)$.

Síndrome febril de origen viral. El cuadro clínico inicial de la infección por arenavirus es indistinguible del producido por otros virus como el dengue. En estudios realizados en Venezuela, la mayor parte de los pacientes infectados por el virus de Guanarito admitidos en un hospital localizado en las zonas endémicas, el diagnóstico clínico fue dengue en el momento de la hospitalización (15). El cuadro es de inicio insidioso con fiebre, escalofrío, cefalea, fotofobia y dolores musculares generalizados. Otros síntomas como náuseas, vómito, diarrea moderada 
and relative bradycardia. Occasionally, neurologic symptoms such as irritability, lethargy or mild ataxia may appear $(15,16)$. By the end of the first week, the first hemorrhagic manifestations occur, including petechiae on the trunk, as well as metrorrhagia. Bloodshot eyes, congestion in mucosae, lymphadenopathy and exanthema may also appear. Although severe in some occasions the condition is severe, hospitalization is required even without the presence of hemorrhage. In most patients the disease fails to progress and condition improves spontaneously. Clinical manifestations vary according to the virus infecting the patient. Patients infected with Guanarito virus show symptoms such as pharyngitis, diarrhea and vomiting, whereas patients infected with Machupo and Junín viruses show erythema and facial edema as well as skin hyperesthesia. Leukopenia and thrombocytopenia are lab alterations accompanying this syndrome. Other alterations such as changes in the levels of transaminases, lactate dehydrogenase (LDH), and kinase creatinine (CK) have also been described $(15,14,22)$.

\section{Hemorrhagic fever with or without encephalopathy neurologic manifestations.} After 8 to 12 days of the onset of the early clinical manifestations, $30 \%$ of the cases show deterioration of the medical condition with shock, severe hemorrhage or serious neurological symptoms (23). Hemorrhagic manifestations are diffuse, bleeding from different puncture sites, hematemesis, hemoptysis, hematuria, and metrorraghia. The Junin virus is associated with a compromise of the central nervous system, mainly shown by a deterioration in the conscience, strong ataxia, convulsions, and coma. These complications may appear in absence of capillary infiltration or hemorrhagic signs. Convulsions are also seen in patients infected with the Guanarito virus in Venezuela $(5,9,15)$. They also show moderate leukopenia and thrombocytopenia, and sedimentation is normal or low. Alterations in the prothrombin and plasma fibrinogen times, even though the deceased is not associated with intravascular disseminated coagulation $(16,18,24,25)$. In the Junin virus infection, there is kidney compromise with alterations in urinary sediment, and urine protein about $1 \mathrm{~g}$, not accompanied by oliguria nor any increase in creatinine, which becomes evident only in the most severe cases. Despite the presence of central nervous system alterations, spinal fluid test is normal. The Junin virus infection is more severe, with a high mortality rate (close to $30 \%$ ). The deceased especially severe in women in their third una hipotensión ortostática y una bradicardia relativa. Ocasionalmente, se ha descrito la presencia de síntomas neurológicos como irritabilidad, letargia o ataxia leve $(15,16)$. Al final de la primera semana se presentan las primeras manifestaciones hemorrágicas, con aparición de petequias a nivel del tronco y metrorragias. También puede ocurrir inyección conjuntival, congestión de mucosas, linfoadenopatías y presencia de un exantema. Aunque en algunas ocasiones el cuadro es severo, aún en ausencia de manifestaciones hemorrágicas, se requiere hospitalización. En la mayoría de los pacientes la enfermedad no progresa y presenta mejoría espontánea. Las manifestaciones clínicas varían según el virus que infecta al paciente. Los pacientes infectados por virus Guanarito presentan síntomas como faringitis, diarrea y vómito, a diferencia de los pacientes infectados por virus Machupo y Junín que presentan eritema y edema facial e hiperestesia de la piel. Las alteraciones de laboratorio que acompañan al síndrome son leucopenia y trombocitopenia. Han sido descritas también alteraciones leves de transaminasas, lactato deshidrogenasa (LDH) y la creatina quinasa (CK) $(15,14,22)$.

Fiebre hemorrágica con o sin manifestaciones neurológicas de encefalopatía. Después de 8 a 12 días del inicio de las primeras manifestaciones clínicas, en el $30 \%$ de los casos se observa empeoramiento del cuadro clínico con aparición de choque, hemorragias severas o síntomas neurológicos graves (23). Las manifestaciones hemorrágicas son difusas, con sangrado en los diferentes sitios de venopunción, hematemesis, hemoptisis, hematuria y metrorragia. El virus Junín se asocia con compromiso del sistema nervioso central, que se manifiesta principalmente por deterioro del estado de conciencia, ataxia marcada, convulsiones y coma. Estas complicaciones pueden estar presentes en ausencia de filtrado capilar o signos hemorrágicos. Las convulsiones también se observan en pacientes infectados por el virus Guanarito en Venezuela $(5,9,15)$. Hay leucopenia y trombocitopenia moderadas, la sedimentación es normal o baja. Se han descrito alteraciones del tiempo de protrombina y del fibrinógeno plasmático, aunque la enfermedad no se asocia con coagulación intravascular diseminada $(16,18,24,25)$. En la infección por virus Junín existe compromiso renal con alteraciones del sedimento urinario, con proteinuria mayor a un gramo, que no se acompaña de oliguria o aumento de la creatinina, la cual se hace evidente solo en los casos más severos. A pesar de la presencia de alteraciones del SNC, el examen del LCR es normal. La infección por virus Junín es más severa, con una alta mortalidad (cerca de $30 \%$ ). La enfermedad es particularmente severa en las mujeres embarazadas, durante el tercer trimestre (21). A diferencia de otras infecciones 
trimester of pregnancy (21). Unlike other viral infections such as yellow fever or hantavirus infections, arenavirus infections produce no specific liver or lung damage. Whenever these organs are compromised, it is secondary to the shock state, to the bacterial superinfection, or hemorrhagic diathesis. Convalescence after a hemorrhagic condition is long, and may last several months, during which the patient suffers marked asthenia and loss of hair. Most of the patients recover with unimportant neurological damage $(5,24,26)$.

\section{Aseptic meningitis and encephalitis by arenavirus of lymphocytic choriomeningitis.}

It produces a 5 to 10 day fever prodrome $(5,24,26)$, similar to other arenaviruses. The only characteristic finding that differentiates this condition from other viral syndromes is the development of orchitis in a small group of patients, parotitis or arthritis in the metacarpophalangeal joints, of late onset during convalescence. Lymphocytic choriomeningitis can also appear as a twostage disease, during which, after the febrile syndrome, neurological manifestations appear ranging from aseptic meningitis to severe encephalitis $(5,24,27)$. Aseptic meningitis is similar to other viral infections, with presence of declared meningeal signs and headache. Spinal fluid analysis shows an increase in pressure and proteins. One characteristic is marked cell presence, with white cell counts above $1000 / \mathrm{uL}$. 20 to $30 \%$ of patients show a mild hipoleucorraquia $(5,24,27)$. Prognosis for the lymphocytic choriomeningitis virus infection is good, and neurological sequelae are scarce. The reservoir for this virus is the cosmopolitan domestic mouse Mus musculus. The lymphocytic choriomeningitis virus being associated in the last years with cases of disseminated infection in patients who have had liver and lung transplants, starting with fever, diarrhea, pain and everything around the incision site and is usually fatal $(23,26)$.

Diagnosis. Diagnosis of fevers caused by arenavirus must be considered in patients with the febrile condition in endemic areas, on which more common infections such as malaria, dengue, and leptospirosis have been ruled out. In Argentina, a suspicious clinical case for endemic regions shows fever, leukopenia under $2.5 / \mathrm{mm}^{3}$, and thrombocytopenia under $10000 /$ $\mathrm{mm}^{3}(28)$. This definition cannot be applied in our environment, since a large part of Columbia is endemic for dengue, and there are many coincidences in the hematologic alterations in both diseases. The differential diagnosis virales como la fiebre amarilla o las infecciones por hantavirus, en las infecciones por arenavirus, no hay daño hepático o pulmonar específico. Cuando existe un compromiso de estos órganos, es secundario al estado de choque, a la sobre infección bacteriana o a la diátesis hemorrágica. La convalecencia después de un cuadro hemorrágico es prolongada y puede durar varios meses, durante los cuales el paciente presenta astenia marcada y pérdida del cabello. La gran mayoría de los pacientes se recuperan sin secuelas neurológicas de importancia $(5,24,26)$.

\section{Meningitis asépticas y encefalitis por el arenavirus de la coriomeningitis linfocitaria.}

Produce pródromo febril de 5 a 10 días $(5,24,26)$, similar a otros arenavirus. El único hallazgo característico, que diferencia este cuadro con el de otros síndromes virales, es el desarrollo en un pequeño grupo de pacientes de orquitis, parotiditis o artritis en las articulaciones metacarpofalángicas, de presentación tardía aún durante la convalecencia. La coriomeningitis linfocitaria puede también presentarse como una enfermedad bifásica, en la que después del síndrome febril, aparecen manifestaciones neurológicas que van desde la meningitis aséptica hasta la encefalitis severa $(5,24,27)$. La meningitis aséptica es similar a otras infecciones virales, con presencia de signos meníngeos declarados y cefalea. El análisis del LCR muestra un aumento de la presión y aumento de proteínas. Es característico es la marcada celularidad, con conteos de leucocitos superiores 1000/ul. En $20 \%$ a $30 \%$ de los pacientes se observa leve hipoleucorraquia $(5,24,27)$. El pronóstico de la infección por el virus de la coriomeningitis linfocitaria, es bueno y las secuelas neurológicas escasas. El reservorio de este virus es el común ratón pequeño domestico cosmopolita Mus musculus. El virus de la coriomeningitis linfocitaria se ha asociado en los últimos años con casos de infección diseminada en pacientes transplantados de hígado y pulmón, que se inicia con fiebre, diarrea, dolor y eritema alrededor de la incisión del sitio de trasplante generalmente es fatal $(23,26)$.

Diagnóstico. El diagnóstico de la de las fiebres por arenavirus debe ser contemplado en pacientes con cuadro febril en las zonas endémicas, en los cuales se han excluido otras infecciones más comunes como malaria, dengue y leptospirosis. En Argentina se define caso clínico sospechoso para regiones endémicas, al que presenta fiebre, leucopenia inferior a $2.5 / \mathrm{mm}^{3}$ y trombocitopenia menor de $10000 / \mathrm{mm}^{3}$ (28). Esta definición no puede ser aplicada en nuestro medio, ya que gran parte de Colombia es zona endémica de dengue y existen muchas coincidencias en las alteraciones hematológicas en las dos enfermedades. El diagnóstico diferencial de la fiebre hemorrágica por 
of hemorrhagic fever by arenavirus must be made first with a severe dengue infection that carries hemorrhagic and neurologic manifestations (6). Cases of encephalopathy that have been described secondary to dengue are indistinguishable from the neurologic manifestations caused by arenavirus $(5,27)$. Other diseases such as malaria, leptospirosis, bacterial sepsis, and rickettsiosis show similar presentations. Therefore, a hemorrhagic fever secondary to arenavirus must be suspected in regions endemic to this disease, in order to rule out the above-mentioned diseases in the lab. It is important to consider diagnosis of lymphocytic choriomeningitis in cases of liver and lung transplants $(27,29,30,31)$.

Lab diagnosis. The rule of thumb is viral isolation during the febrile period, which may be done through a throat swab, urine, spinal fluid, or tissue samples. This technique implies direct contact with the virus, which is highly infecting, and therefore it must be carried out only in labs with category 4 biosecurity. During some years, specific RNA-PCR for arenavirus have been created which may be used in category three labs $(6,32,33)$.

In practice, serology is the most common used method to diagnose the disease. In a patient with a compatible clinical condition, the presence of a positive ELISA titer or positive IFA IgM, allows for a presumptive diagnosis, which must be confirmed with a seroconversion three weeks later, and an increase in IgG titers after 4 weeks. There are no commercial test for arenavirus, and only specialized research groups and public health laboratories have ELISA or IFI tests. There is an important crossreactivity between different types of viruses, and therefore the specific diagnosis can only be made with neutralizing antibodies, which appear between 12 and 30 days of symptom onset and during convalescence $(6,32,33,34)$.

\section{Arenavirus in South America}

The Argentinian hemorrhagic fever (FHA) was first described a similar pathology in the early 1950s; in 1958 its a etiologic agent was reported as Junín virus (JUNV), a member of the Arenaviridae family. The Calomys musculinus is identified as the main reservoir (22). Currently, the FHA endemic area encompasses 150,000 $\mathrm{km}^{2}$ in the provinces of Buenos Aires, Santa Fe, and Córdoba, the population of over 5 million people at risk. Over $70 \%$ of the cases notified our men between ages 10 and 39. In 1959 the Bolivian hemorrhagic fever was clinically recognized in the provinces of Mamoré, Itenez, arenavirus, debe hacerse en primer lugar con la infección severa por el virus del dengue que cursa con manifestaciones hemorrágicas y neurológicas (6). Se han descrito casos de encefalopatía secundaria al dengue que son indistinguibles de los cuadros neurológicos causados por arenavirus $(5,27)$. Otras enfermedades como malaria, leptospirosis, sepsis de origen bacteriano y rickectsiosis, tienen presentaciones similares. Por esta razón, la fiebre hemorrágica secundaria a arenavirus debe sospecharse en las regiones endémicas para esta enfermedad, después de descartar por medio de laboratorio las enfermedades anteriores. Es importante considerar en el diagnóstico la coriomeningitis linfocitaria, en casos de trasplantes de hígado y pulmón $(27,29,30,31)$.

Diagnóstico de laboratorio. La prueba de oro es el aislamiento viral durante el periodo febril, el cual puede ser realizado de hisopado laríngeo, orina, líquido cefalorraquídeo o muestras de tejido. Esta técnica implica el contacto directo con el virus que es altamente infectante, por lo que debe realizarse solamente en laboratorios de nivel de bioseguridad categoría cuatro. Desde hace algunos años han sido creadas ARN-PCR específicas para arenavirus que pueden ser utilizadas en laboratorios de categoría tres $(6,32,33)$.

En la práctica, la serología es el método más común utilizado para el diagnóstico de la enfermedad. En un paciente con cuadro clínico compatible, la presencia de un título de ELISA o IFA IgM positivo, permite hacer un diagnóstico presuntivo, el cual debe confirmarse, con seroconversión a las 3 semanas y aumento de los títulos de IgG a las 4 semanas. No existen pruebas comerciales para arenavirus, solo los grupos de investigación especializados y grandes laboratorios de salud pública poseen pruebas de ELISA o IFI. Existe una importante reactividad cruzada entre los diferentes tipos de virus, por lo que el diagnóstico específico solo puede realizarse por medio de anticuerpos neutralizantes, los cuales aparecen entre 12 a 30 días del inicio de los síntomas y durante la convalecencia $(6,32,33,34)$.

\section{Arenavirus en Suramérica}

La fiebre hemorrágica argentina (FHA) fue descrita la primera vez como una nueva patología a comienzos de la década de 1950, en 1958 se reportó su agente etiológico como virus Junín (JUNV), integrante de la familia Arenaviridae. El ratón de campo Calomys musculinus se identifica como el reservorio principal (22). En la actualidad, el área endémica de FHA ocupa $150.000 \mathrm{Km}^{2}$ en las provincias de Buenos Aires, Santa Fe y Córdoba, con una población en riesgo de 5.000 .000 de personas. Más del $70 \%$ de los casos notificados corresponden a hombres entre 
and Yacuma, department of Beni. Between 1963 and 1964 and epidemic struck San Joaquín, capital of Mamoré, with 650 cases and 122 deaths within a population of 2500 people. All of these cases were caused by the Machupo arenavirus hosted by the Callomys callosus rodent. Sporadic cases of this zoonosis continue to appear. In 2008, a new arenavirus named Chapare was isolated in a fatal case of Bolivian hemorrhagic fever $(3,21)$. The rodent that serves as a reservoir for this virus has not been identified.

In 1989, for the first time in the Venezuelan state of Portuguesa, a new disease appeared mainly affecting workers in sugarcane and cotton plantations, in the municipality of Guanarito and its neighboring areas. The 1990 that agent was identified, a new arenavirus that was named Guanarito, etiologic agent of the new disease known as Venezuelan hemorrhagic fever (FHV) $(6,25,28)$.

So far, rodents Zygodontomys brevicauda and Sigmodon alstoni have been established as the natural reservoirs of the

Guanarito arenavirus. In 1990, in Brazil, the Sabiá virus (4) was isolated from a fatal case of hemorrhagic fever in São Paulo, and host of the arenavirus is unknown. In 2011, in the Colombian department of Córdoba in the Caribbean coast, the presence of antibodies in rodents of the Zygodontomys brevicauda species was determined, yielding a seroprevalence of $1.1 \%$ of the Guanarito arenavirus (10). (Figure 1 ).

Treatment. Even though the arenavirus infection is a potentially deadly disease, most of the patient present a moderate severity condition, that only needs proper hydration antipyretics and anti-inflammatories $(17,35,36)$. The care of patients with severe signs must include some aggressive management. There are four crucial points in this treatment: a) early recognition of severe cases; b) isolation; c) admission to intensive care units; d) antiviral drug supply.

Early recognition of severe cases. Patients with comorbidities such as kidney failure, diabetes or heart failure, and pregnant women especially, have a higher mortality rate and therefore must be hospitalized (27). Proper assessment of shock signs and hemorrhagic manifestations must be ensured for all patients.
10 y 39 años. En 1959 se reconoció clínicamente la fiebre hemorrágica boliviana, en las provincias de Mamoré, Itenez y Yacuma departamento de Beni. Entre los años 1963 1964, se presentó una epidemia en San Joaquín, capital de Mamoré, en donde se presentaron 650 casos y 122 defunciones de una población cercana a los 2500 habitantes. Todos estos casos fueron ocasionados por arenavirus Machupo cuyo hospedero es el roedor Callomys callosus. Actualmente se siguen presentando casos esporádicos de esta zoonosis. En 2008, fue aislado un nuevo arenavirus denominado Chapare, en un caso fatal de fiebre hemorrágica boliviana $(3,21)$. El roedor reservorio para este virus no ha sido identificado.

En 1989, apareció por primera vez en el estado de Portuguesa en Venezuela, una nueva enfermedad que afectaba principalmente a trabajadores de los cultivos de caña de azúcar y algodón, en el municipio Guanarito y las áreas vecinas. En 1990 se identificó el agente causal, un nuevo arenavirus que se denominó virus Guanarito, agente etiológico de la nueva enfermedad conocida como fiebre hemorrágica venezolana (FHV) $(6,25,28)$.

Se ha establecido hasta el momento que los roedores Zygodontomys brevicauda y Sigmodon alstoni son los reservorios naturales del arenavirus Guanarito. En 1990, en Brasil, el virus Sabiá (4) fue aislado de un caso fatal de fiebre hemorrágica en Sao Paulo, se desconoce el hospedero de arena virus. En 2011, en Córdoba departamento del Caribe Colombiano, se determinó la presencia de anticuerpos en roedores del género Zygodontomys brevicauda y se obtuvo una seroprevalencia de $1.1 \%$ del arenavirus Guanarito (10). (Figura 1).

Tratamiento. Aunque la infección por arenavirus es una enfermedad potencialmente mortal, la mayor parte de los pacientes presentan un cuadro de gravedad moderada, que necesita solamente adecuada hidratación y antipiréticos y antiinflamatorios $(17,35,36)$. La atención de los pacientes con signos de severos debe tener un manejo agresivo. Existen cuatro puntos cruciales en este manejo: a) reconocimiento precoz de los casos severos; b) aislamiento; c) admisión en cuidados intensivos; d) suministro de fármacos antivirales.

Reconocimiento precoz de los casos severos. Los pacientes con co-morbilidades como insuficiencia renal, diabetes o falla cardiaca y especialmente las embarazadas, tienen un riesgo de mortalidad mayor y por lo tanto deben ser hospitalizados (27). Una adecuada valoración de los signos de choque y de las manifestaciones hemorrágicas, debe ser asegurada a todos los pacientes. 
Patient isolation. All arenavirus is our infectious when airborne. Intra-hospital transmission of other arenaviruses such as Lassa virus is a public health problem in Africa (27). Some observations indicate that patients infected by Junín, Manchupo, and Sabiá viruses who are severely sick and with an elevated viremia may transmit the virus from one person to another by air. Therefore, isolation to prevent contact with blood, but in the fluids, and respiratory secretions is recommended for this type of patients $(5,38,39)$.

Admission to intensive care. Most of the texts that deal with tropical diseases that lack of specific therapy vaguely mention support measures. However, due to the global dengue epidemic, several researchers have demonstrated that aggressive management of tropical viral diseases through clinical protocols is associated with a reduction of mortality rates even in the absence of specific antiviral drugs.

Just as in the Dengue case, arenavirus infections may produce a shock even without hemorrhages (37-39). Early management of this condition with corticoids can help reduce mortality. Since this is a senior condition with a bad prognosis, the patient must be transferred to an intensive care unit, where they can receive continuous monitoring, respiratory support, red blood cell or platelet transfusions, and correction of metabolic and electrolytic imbalances (5). Junín virus infections, which frequently become complicated with alterations of consciousness, agitation and convulsions, provision of benzodiazepines and other anticonvulsant drugs as well as respiratory support in case of comma, play a role in managing these patients (5).

Provision of antiviral drugs and immune plasma. Since the 50s, plasma extracted from people who have been previously infected with the Junín virus has been used in treating severe cases of Argentinian hemorrhagic fever. Control essays have demonstrated the effectiveness of this treatment in reducing mortality rates up to $30 \%$. However, $10 \%$ of the patients treated in this way show a neurologic deterioration characterized by fever, cerebellar signs and palaces of the cranial nerves (6). Onset of this syndrome, and the difficulty to keep a deposit of human immune plasma have become constraints for the use of this treatment in endemic areas $(6,27)$. Another alternative lies in the use of Ribavirin, which was introduced in the mid-80s. In cultural clinical studies, the use of this medication has not produced a mortality
Aislamiento del paciente. Todos los arenavirus son infectivos en estado de aerosol. La transmisión intrahospitalaria de otros arenavirus como Lassa virus, es un problema de salud pública en África (27). Existen algunas observaciones que indican que los pacientes infectados por los virus Junín, Manchupo y Sabiá, que están gravemente enfermos y presentan una viremia elevada, pueden transmitir el virus de persona a persona a través de vía aérea. Por lo que es aconsejable un aislamiento que evite el contacto con sangre, fluidos corporales y secreciones respiratorias, en este tipo de pacientes $(5,38,39)$.

Admisión en cuidados intensivos. En la mayoría de los textos en los cuales se tratan las enfermedades tropicales es usual cuando se discuten las enfermedades tropicales que carecen de una terapia específica se mencionan vagamente las medidas de soporte. Sin embargo, a causa de la epidemia global de Dengue, ha sido demostrado por diferentes investigadores que el manejo agresivo de las enfermedades virales tropicales, a través de protocolos clínicos se asocia con una reducción de la mortalidad aún en ausencia de fármacos antivirales específicos.

Como en el caso del Dengue, las infecciones por arenavirus pueden producir un cuadro de choque aún en ausencia de hemorragias (37-39). La gestión precoz de este cuadro con el suministro de corticoides puede ayudar en la reducción de la mortalidad. Como se trata de un cuadro severo con mal pronóstico, el paciente debe ser trasladado a la unidad de cuidado intensivo, donde puede recibir además de un monitoreo continuo, un soporte respiratorio, transfusiones de eritrocitos o plaquetas y corrección de los desbalances metabólicos y electrolíticos (5). En el caso de infecciones por el virus Junín, las cuales se complican frecuentemente con alteraciones del estado de conciencia, con agitación y convulsiones, el suministro de benzodiazepinas y otros fármacos anticonvulsivantes y soporte ventilatorio en el caso de coma, juegan un rol en el manejo de estos pacientes (5).

Administración de fármacos antivirales y plasma inmune. Desde los años 50 , se ha utilizado el suministro de plasma extraído de personas que han presentado una infección previa por el virus Junín, en el tratamiento de los casos severos de fiebre hemorrágica Argentina. Existen ensayos controlados que han demostrado la efectividad de este tratamiento en la reducción de la mortalidad hasta de un 30\%. Sin embargo, un $10 \%$ de los pacientes tratados de esta manera presentan un cuadro de deterioro neurológico caracterizado por fiebre, signos cerebelares y parálisis de los nervios craneales (6). La aparición de este síndrome y la 
reduction, although it has been associated with a significant reduction of viremia $(6,27)$. As for specific treatments for other virus other than Junín, there is not enough data to recommend other measures different event support therapy in an intensive care unit. dificultad para mantener un depósito de plasma inmune humano se han constituido en barreras para el uso de este tratamiento en las áreas endémicas $(6,27)$. La otra alternativa es el uso de Ribavirina, la cual fue introducida a mediados de los años 80. En los estudios clínicos controlados, el uso del medicamento no ha demostrado una disminución de la mortalidad, aunque se ha asociado con una reducción significativa de la viremia $(6,27)$. Con respecto a los tratamientos específicos de otros virus diferentes al Junín, no existen datos suficientes para recomendar otras medidas diferentes a una terapia de soporte en una unidad de cuidado intensivo.

\section{REFERENCIAS}

1. McLay L, Liang $Y$, Hinh L. Comparative analysis of disease pathogenesis and molecular mechanisms of new world and old world arenavirus infections. J Gen Virol. 2014;95:1-15

2. Briggiler $A$, Sinchi $A$, Coronel $F$, Sánchez Z, Levis S, Taylor J, et al. Los nuevos escenarios de transmisión de la fiebre hemorrágica Argentina desde la introducción de la vacuna a virus Junín vivo atenuado (candid\#1): una experiencia en trabajadores golondrinas. Rev Peru med Exp Salud pública. 2015;32(1):165-171.

3. Delgado $S$, Erickson BR, Agudo R, Blair PJ, Vallejo E, Albariño CG, et al. Chapare virus, a newly discovered arenavirus isolated from a fatal hemorrhagic fever case in Bolivia. PLoS Pathog. 2008; 4:1-6.

4. Cajimat MN, Milazzo ML, Rollin PE, Nichol ST, Bowen MD, Ksiazek TG. Genetic diversity among Bolivian arenaviruses. Virus Res. 2009; 140(1-2):24-31.

5. Trapido $H$, SanMartín C. Pichindé virus a new virus of the Tacaribe group from Colombia. Am J Trop Med Hyg. 1971; 20:631-641.

6. Enría DA, Mills JN, Bausch D, Shieh WJ, Peters C.J. Arenavirus. En: Guerrant R, Walker D, Weller P. Tropical Infectious Diseases. Third Edition. Saunders. Elsevier. 2011.
7. Radoshitzky SR, Bao Y, Buchmeier MJ, Charrel RN, Clawson AN, Clegg CS, et al. Past, present, and future of arenavirus taxonomy. Arch Virol. 2015; 160:1851-1874.

8. Aguilar PV, Camargo W, Vargas J, Guevara C, Roca Y, Felices V, et al. Reemergence of Bolivian hemorrhagic fever, 2007-2008. Emerg Infect Dis. 2009; 15:1526-1528.

9. Gryseels S, Baird SJE, Borremans B, Makundi $R$, Leirs $H$, et al. When viruses don't go viral: The importance of host phylogeographic structure in the spatial spread of arenaviruses. 2017. PLOS Pathogens 13(1): e1006073. doi: 10.1371/ journal.ppat. 1006073

10. Mattar S, Guzman C, Arrazola J, Soto E, Barrios J, Pini N, et al. Antibody to arenaviruses in rodents, Caribbean Colombia. Emerg Infect Dis. $2011 ; 17: 1315-357$.

11. Restrepo B, Rodas JD, Montoya-Ruiz C, Zuluaga AM, Parra-Henao G, Agudelo-Flórez P. Evidencia serológica retrospectiva de infecciones por Leptospira spp., dengue, hantavirus y arenavirus en indígenas Emberá-Katio, Colombia. Rev. chil. Infectol. 2016;33(4): 472-473. 
12. Castellar A, Guevara M, Rodas JD, Londoño AF, Arroyabe E, Díaz FJ, et al. Primera evidencia de infección por el virus de la coriomeningitis linfocítica (arenavirus) en roedores Mus musculus capturados en la zona urbana del municipio de Sincelejo (Sucre, Colombia). Biomédica. 2017;37(Sp.1). Citación provisional.

13. Bowen MD, Peters CJ, Nichol ST. The phylogeny of new world (Tacaribe Complex) arenaviruses. Virology. 1996; 219:285-290.

14. Rodas JD, Salvato M. Tales of mice and men: Natural history of arenaviruses. Rev Col Cienc Pec. 2006;19(4):382-400.

15. Reguera J, Gerlach P, Rosenthal M, Gaudon S, Coscia F, Günther S, et al. Comparative Structural and Functional Analysis of Bunyavirus and Arenavirus CapSnatching Endonucleases. PLoS Pathog. 2016;12(6):e1005636. doi: 10.1371/ journal.ppat. 1005636

16. Martínez-Sobrido L, de la Torre JC. Reporter-expressing, replicating-competent recombinant arenaviruses. Viruses. 2016;8(7):197; doi:10.3390/v8070197

17. Crispin M, Zeltina A, Zitzmann N, Bowden T. A Native functionality and therapeutic targeting of arenaviral glycoproteins. Current Opinion in Virology. 2016;18:70-75.

18. Patterson M, Grant A, Paessler S. Epidemiology and pathogenesis of Bolivian hemorrhagic fever. Curr Opin Virol. 2014;5:82-90.

19. Moraes FLT. Febres hemorrágicas por vírus no Brasil. Revista da Sociedade Brasileira de Medicina Tropical. 2006;39(2):203-210.

20. Center for Food Security \& Public Health (CFSPH), Insitute for international Cooperation in Animal Biologics (IICA), Viral hemorrhagic fevers caused by arenaviruses. 2010:1.9. Tomado de: http://www. cfsph.iastate.edu/Factsheets/pdfs/viral_ hemorrhagic_fever_arenavirus.pdf

21. Grant A, Seregin A, Huang C, Kolokoltsova $O$, Brasier A, Peters $C$, et al. Junín virus pathogenesis and virus replication, Viruses 2012;4:2317-2339.
22. Soto E, Mattar S. Fiebres hemorrágicas por Arenavirus en Latinoamérica. Revista Científica Salud Uninorte. 2010;26(2): 298-310

23. Ireland DC, Tami C, Pedras-Vasconcelos J, Verthelyi D. CD4 and CD8 T cells mediate distinct lethal meningoencephalitis in mice hallenged with Tacaribe arenavirus. Cell. Mol. Immunol. 2017;14:90-106.

24. Harrison LH, Halsey NA, McKee Jr KT, Peters CJ, Barrera-Oro JG, Briggiler AM, et al. Clinical case definitions for Argentine Hemorrhagic Fever. Clin Infect Dis. 1999; 28:1091-1094.

25. Weaver SC, Salas RA, de Manzione N, Fulhorst CF, Duno G, Utrera A, et al. Guanarito virus (Arenaviridae) isolates from endemic and outlying localities in Venezuela: Sequence comparisons among and within strains isolated from Venezuelan hemorrhagic fever patients and rodents. Virology. 2000; 266:189-195.

26. Salas $R$, Pacheco ME, Ramos B, Taibo ME, Jaimes E, Vasquez C, et al. Venezuelan haemorrhagic fever. Lancet 1991; 338:10331036.

27. Ippolito $G$, Feldmann $H$, Lanini S, Vairo F, Di Caro A, Capobianchi, et al. Viral hemorrhagic fevers: advancing the level of treatment. BMC Medicine 2012, 10:31. doi: 10.1186/1741-7015-10-31.

28. de Manzione N, Salas RA, Paredes $\mathrm{H}$, Godoy O, Rojas L, Araoz F, et al. Venezuelan hemorrhagic fever: clinical and epidemiological studies of 165 cases. Clin Infect Dis. 1998; 26:308-313.

29. Peters CJ. Lymphocytic choriomeningitis virus, Lassa virus, and the South American hemorrhagic fevers. In: Mandell GL, Bennett JE, Dolin R, editors. Mandell, Douglas, and Bennett's principles and practice of infectious diseases, 7th ed. Philadelphia: Churchill Livingstone Elsevier; 2010. p. 2295-301.

30. Pérez-Ruiz M, Navarro-Marí JM, SánchezSeco MP, Gegúndez MI, Palacios G, Savji N, et al. Lymphocytic choriomeningitis virusassociated meningitis, southern Spain. Emerg Infect Dis. 2012; 18:855-858. 
31. Macneil A, Ströher U, Farnon E, Campbell S, Cannon D, Paddock $C D$, et al. Solid Organ Transplantassociated Lymphocytic Choriomeningitis, United States, 2011. Emerg Infect Dis. 2012; 18:1256-1262.

32. Fukushi S, Tani H, Yoshikawa T, Saijo M, Morikawa S. Serological assays based on recombinant viral proteins for the diagnosis of arenavirus hemorrhagic fevers. Viruses. 2012; 4(10):2097-114.

33. Stefan PC, Chase K, Coyne S, Kulesh DA, Minogue TD, Koehler JW. Development of real-time reverse transcriptase qPCR assays for the detection of Punta Toro virus and Pichindé virus. Virol J. 2016; 13:54 10.1186/s12985-016-0509-3.

34. Shuetsu F, Hideki T, Tomoki Y, Masayuki $S$, Shigeru M. Serological assays based on recombinant viral proteins for the diagnosis of arenavirus hemorrhagic fevers. Viruses. 2012;4: 2097-2114; doi:10.3390/ v4102097

35. Chenga BYH, Nogalesa A, de la Torre JC, Martínez-Sobrido L. Development of liveattenuated arenavirus vaccines based on codon deoptimization of the viral glycoprotein Virology. 2017;15 (501):35-46.

36. Koma T, Huang C, Aronson JF, Walker AG, Miller M, Smith JN, et al. The ectodomain of glycoprotein from the candid\# 1 vaccine strain of Junín virus rendered Machupo virus partially attenuated in mice lacking IFN- $a \beta / Y$ receptor. PLoS Negl Trop Dis. 2016;10(8): e0004969. doi:10.1371/ journal. pntd.0004969.
37. Ranjit S, Kissoon N, Jayakumar I. Aggressive management of dengue shock syndrome may decrease mortality rate: a suggested protocol. Pediatr Crit Care Med 2005; 6:412-419.

38. Johnson KM, Wiebenga $\mathrm{NH}$, Mackenzie RB, Kuns ML, Tauraso NM, Shelokov A, et al. Virus isolations from human cases of hemorrhagic fever in Bolivia. Proc Soc Exp Biol Med. 1965; 118:113-118.

39. Grove JN, Branco LM, Boisen ML, Muncy I, Henderson LA, Schieffellin JS, et al. Capacity building permitting comprehensive monitoring of a severe case of Lassa hemorrhagic fever in Sierra Leone with a positive outcome: Case Report. Virol J. 2011; 8:314. doi: $10.1186 / 1743-422 X-8-314$.

40. Nhi N, Schimmelpfeng HK, Cisneros MI, Cubitt B, Iwasaki M, de la Torre JC, et al. Correction for $\mathrm{Ngo}$ et al., Identification and mechanism of action of a novel small-molecule inhibitor of arenavirus multiplication. J Virol. 2016; 90:18.8381. doi:10.1128/JVI.01289-16. 